Marquette University

e-Publications@Marquette

Chemistry Faculty Research and Publications

Chemistry, Department of

4-1-2012

\title{
Visible and Infrared Spectroelectrochemistry of Cobalt Porphinones and Porphinediones
}

Florentina Tutunea

Marquette University

Michael D. Ryan

Marquette University, michael.ryan@marquette.edu

Accepted version. Journal of Electroanalytical Chemistry, Vol. 670 (April 2012): 16-22. DOI. (C) 2012 Elsevier. Used with permission. 


\title{
Visible and Infrared Spectroelectrochemistry of Cobalt Porphinones and Porphinediones
}

\author{
Florentina Tutunea \\ Department of Chemistry, Marquette University \\ Milwaukee, WI \\ Michael D. Ryan \\ Department of Chemistry, Marquette University \\ Milwaukee, WI
}

\begin{abstract}
The visible and infrared spectroelectrochemistry of the redox chemistry of $\mathrm{CO}^{\mathrm{II}}$-porphinone complexes were examined and compared with similar studies of the respective iron complexes. Cobalt(II) porphinone complexes undergo a one-electron reduction and two one-electron oxidations within the potential region that was studied in this work. The one electron spectroelectrochemical reduction of $\mathrm{Co}^{\mathrm{II}}(\mathrm{P})(\mathrm{P}=$ octaethylporphyrin $(\mathrm{OEP})$, octaethylporphinone (OEPone), and octaethylporphinedione (OEPdione)) were studied using visible spectroscopy, and their cobalt(I) complexes were characterized. The same reduction was examined by FTIR spectroscopy for $\mathrm{P}=$ OEPone and OEPdione. The infrared spectra showed downshifts of the $v_{c o}$ band that were consistent with a cobalt(I) complex and were similar to the iron(I) complex. The two one-electron oxidations of $\mathrm{Co}^{\mathrm{II}}$ (OEPone) and $\mathrm{Co}^{\mathrm{II}}$ (OEPdione) were also carried out using visible and infrared spectroelectrochemistry. The $v$ co band for cobalt was less sensitive to the metal oxidation state (III vs. II) than was observed in the iron complexes.
\end{abstract}


NOT THE PUBLISHED VERSION; this is the author's final, peer-reviewed manuscript. The published version may be accessed by following the link in the citation at the bottom of the page.

Additional upshifts in the $v$ co band were observed for the $n$-cation radical. Isotopic ${ }^{18} \mathrm{O}$ substitution on the carbonyl group of the $\mathrm{H}_{2} \mathrm{OEPone}$ was done in order to determine the degree of mixing up the porphinone modes with the carbonyl vibrations.

Keywords: zinc, manganese, iron, cobalt, DFT calculations, porphyrin, porphinone, cyclic voltammetry, spectroelectrochemistry, visible, infrared

\section{Introduction}

Nature has shown us that a rich diversity of porphine related structures, many of them involved in enzymes that are part of the nitrogen cycle. For example, the active site in many assimilatory nitrite/sulfite reductases contains a siroheme, an iron isobacteriochlorin. In cytochrome $\mathrm{cd}_{1}$, which is present in some dissimilatory nitrite reductases, the enzyme contains a heme $d_{1}$, which is an iron porphinonedione. Recent work in our laboratory has reported on the infrared spectroelectrochemistry of iron porphinones [1]. The focus of this work was to study the electronic structure of low valence iron porphyrins by monitoring in the carbonyl frequency in the infrared spectra, and comparing the results to the DFT calculated spectra. The frequency of the carbonyl band should be an indication of the extent of the delocalization of the electronic density onto the macrocycle ring. In the iron(III) porphinone complex, the first reduction led to a downshift of $16 \mathrm{~cm}^{-1}$ for this band. Further reduction to the formal $\mathrm{Fe}(\mathrm{I}) \mathrm{complex}$ gave rise to a downshift of $32 \mathrm{~cm}^{-1}$. DFT calculations show that the complex had considerable $\mathrm{Fe}(\mathrm{I})$ character with some delocalization to the macrocycle.

Starting with Co(III) porphyrin complexes, the first two reductions (Co(III)/Co(II) and $\mathrm{Co}$ (II)/Co(I)) are predominantly metal centered [2], [3], [4] and [5]. The visible spectrum [6] and X-ray structure [7] of Co(I)TPP- have been obtained, and it has been shown to be a low spin complex. The visible spectroelectrochemistry of $\mathrm{Co}^{\mathrm{II}}$ (TPP) reduction was carried out by Kadish et al. [2] and [3]. No studies of the spectroelectrochemical reduction of the $\mathrm{Co}$ (II)-alkyl substituted porphyrins have been reported. The oxidation of $\mathrm{Co}^{\mathrm{II}}(\mathrm{OEP})$ (and other metal complexes) was studied using infrared spectroelectrochemistry by Hinman and Olorunyolemi [8], which followed an earlier report, using the same technique, for the oxidation of manganese, iron and cobalt tetraphenylporphyrins [9] and [10]. The 
spectroelectrochemistry of iron complexes of porphinones and porphinediones has been intensively studied in our laboratory [1], [11] and [12].

The oxidation of Co(II) porphyrins has been extensively studied [13], [14], [15], [16] and [17]. In coordinating media, cobalt(II) is oxidized to cobalt(III) with either solvent or anionic coordination [2]. In non-coordinating media, the cobalt(II) $n$-cation radical is formed [14]. The latter oxidation generally leads to a reversible voltammogram [3], while the formation of cobalt(III) yields a very quasi-reversible wave. In order to better characterize the spectral changes observed, the infrared and visible spectroelectrochemistry of cobalt porphinone and porphinedione complexes were examined (the ligand structures are shown in Scheme 1). The study should help us to better document the spectral changes in the iron porphinone complexes which are proposed to be related to the metal oxidation state.

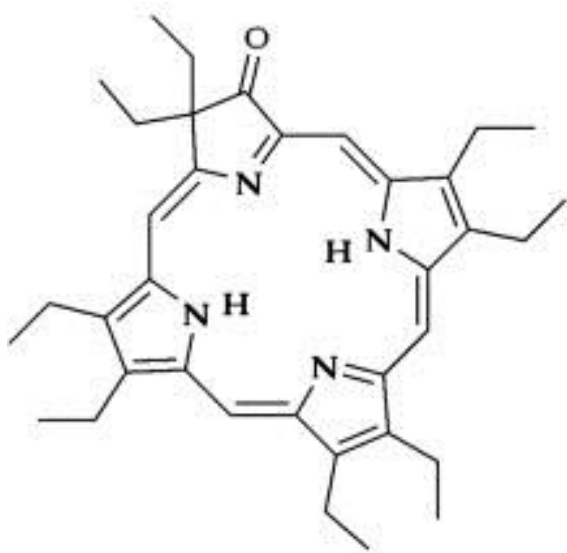

Octaethylporphinone (OEPone)

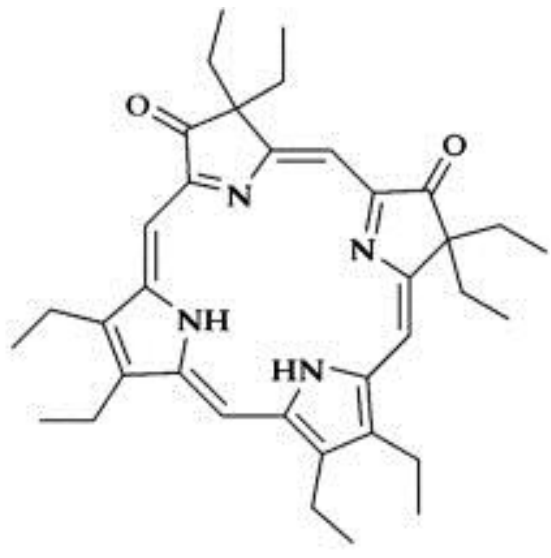

Octaethylporphinedione (OEPdione)

Scheme 1. Structures for porphinone macrocycles used in this work.

\section{Experimental}

\subsection{Chemicals}

Octaethylporphyrin ( $\left.\mathrm{H}_{2} \mathrm{OEP}\right)$ was purchased from Sigma-Aldrich Chemical Co. Tetrabutylammonium perchlorate was purchased from Alfa Aesar and dried at $90^{\circ} \mathrm{C}$ in a vacuum oven overnight. Anhydrous tetrahydrofuran (THF) was refluxed in the presence of sodium and 
benzophenone under nitrogen until the solution was blue. The solution was deoxygenated at least three times by freeze-pump-thaw cycles before being used in the glove-box. All other solvents were spectrophotometric grade and used without further purification. Octaethylporphinone ( $\left.\mathrm{H}_{2} \mathrm{OEPone}\right)$ and octaethylporphinedione ( $\mathrm{H}_{2}$ OEPdione) were synthesized by literature methods [18], [19] and [20]. Cobalt(II)-OEPone and cobalt(II)-OEPdione were synthesized by the reaction of cobalt acetate tetrahydrate in a $\mathrm{CHCl}_{3} /$ methanol mixture at reflux for $24 \mathrm{~h}$. The resulting solution was cooled at room temperature and washed three times with deionized water. After removing the solvent, the crude material was purified on a silica gel column using chloroform as an eluent.

\subsection{Synthesis of ${ }^{18} \mathrm{O}-\mathrm{H}_{2} \mathrm{OEP}$ one}

Trifluoroacetic acid (TFA, $15 \mu \mathrm{L})$ and $\mathrm{H}_{2}{ }^{18} \mathrm{O}\left(97 \%{ }^{18} \mathrm{O}\right.$ atom, $0.18 \mathrm{~mL}$ ) were added to a toluene $(6 \mathrm{~mL})$ solution of $\mathrm{H}_{2}$ OEPone (20 mg). The solution turned from purple to blue. The mixture was stirred at $70^{\circ} \mathrm{C}$ under an inert atmosphere for 4 days using a condenser. The mixture was then allowed to cool, and was neutralized with an aqueous $4 \% \mathrm{NaHCO}_{3}$ solution, stirring for 5 min. The mixture was transferred to a separatory funnel, and the organic phase was washed three times with deionized water, filtered and evaporated to give the ${ }^{18} \mathrm{O}$ labeled porphyrin. FTIR analysis indicated over $87 \%$ isotopic substitution.

\subsection{Equipment}

The UV-visible spectra were recorded on a Hewlett-Packard 8452A diode array spectrophotometer with an OLIS data acquisition system. An optically transparent thin layer electrode (OTTLE) cell was used for visible spectroelectrochemistry. The cell assembly was based on the design of Lin and Kadish [21]. A silver wire was used as a reference electrode. The electrode potentials that corresponded to each spectra were obtained using an E-corder (eDAQ Pty Ltd., Australia), which was controlled by the software program, Chart (eDAQ). Each time that the diode array slit opened (every $5.0 \mathrm{~s}$, except as noted), the E-corder was triggered to acquire the potential from the potentiostat. The potentials recorded in this work were the

Journal of Electroanalytical Chemistry, Vol. 670 (April 1, 2012): pg. 16-22. DOI. This article is (C) Elsevier and permission has been granted for this version to appear in e-Publications@Marquette. Elsevier does not grant permission for this article to be further copied/distributed or hosted elsewhere without the express permission from Elsevier. 
average potentials during the spectral acquisition time $(1.0 \mathrm{~s})$. The infrared spectra were obtained with a Thermo Nicolet-FTIR spectrophotometer (Model 670 Nexus) with a MCT detector. Infrared spectra of solid materials were collect as $\mathrm{KBr}$ pellets. The FTIR OTTLE cell has been described previously [1].

\subsection{Procedures}

All samples for spectroelectrochemical analysis were prepared and the cells filled in the glove box under argon. The supporting electrolyte was 0.10 M TBAP. Most FTIR spectra were obtained using 32 scans, and $2 \mathrm{~cm}^{-1}$ resolution unless noted differently. The UVvisible spectra were obtained from cyclic scans of the potential, while FTIR spectra were obtained at constant potential. All potentials are reported vs. SCE ( $V$ vs. SCE $=V$ vs. $\mathrm{Ag} / \mathrm{AgClO}_{4}+0.17 \mathrm{~V}$ ). In some cases, small amounts of residual starting material could be observed in the final spectrum due to the fact that the working electrode did not cover the entire beam. In these cases, the residual amounts were digitally subtracted in order to obtain the final spectrum of the oxidized/reduced species. For all the spectroelectrochemical experiments (visible and infrared), the potential was returned to the initial potential after the experiment was completed in order to verify that the starting spectrum could be recovered. This indicated that an irreversible chemical reaction had not occurred. This condition was fulfilled for all reported spectra.

\subsection{Computation}

Electronic structure and vibrational spectral calculations were carried out using BP86 DFT functional and TZVP basis set for all elements except cobalt using the Gaussian 09 suite of programs [22]. The Wachters' basis set was used for cobalt and iron [23]. All calculations converged using the tight optimization criteria. Natural bond orbital (NBO) analysis was carried out on all converged structures. The DFT structures of the $n$-cation radicals of cobalt(III) porphinones were not investigated in this work, and poor convergence did not allow us to obtain vibrational spectra for Fe ${ }^{\mathrm{II}}$ (OEPdione) and $\mathrm{Co}^{\mathrm{II} / \mathrm{I}}(\mathrm{OEP} d i o n e)$.

Journal of Electroanalytical Chemistry, Vol. 670 (April 1, 2012): pg. 16-22. DOI. This article is (C) Elsevier and permission has been granted for this version to appear in e-Publications@Marquette. Elsevier does not grant permission for this article to be further copied/distributed or hosted elsewhere without the express permission from Elsevier. 
NOT THE PUBLISHED VERSION; this is the author's final, peer-reviewed manuscript. The published version may be accessed by following the link in the citation at the bottom of the page.

\section{Results and discussion}

\subsection{Visible spectroelectrochemistry of cobalt porphyrins and porphinones}

Cobalt(II) porphinones are reduced by one-electron and oxidized by two one-electron steps within the potential range studied. To maintain a known coordination of the cobalt(III) complexes, chloride as tetraphenylphosphonium chloride (TPPCl), was added to the solution. The three one-electron steps are summarized below:

$$
\begin{aligned}
& \mathrm{Co}^{\mathrm{II}} \text { (Pone) }+\mathrm{e}^{-} \rightarrow \mathrm{Co}(\text { Pone })^{-} \\
& \mathrm{Co}^{\mathrm{II}}(\text { Pone })+\mathrm{Cl}^{-} \rightarrow \mathrm{Co}^{\mathrm{III}} \text { (Pone) } \mathrm{Cl}^{+} \mathrm{e}^{-} \\
& \mathrm{Co}^{\mathrm{III}}(\text { Pone }) \mathrm{Cl} \rightarrow \mathrm{Co}^{\mathrm{III}} \text { (Pone) } \mathrm{Cl}^{+}+\mathrm{e}^{-}
\end{aligned}
$$

Cyclic voltammetry of $\mathrm{Co}^{\mathrm{II}}$ (Pone) (Pone = octaethylporphinone or octaethylporphinedione) showed that Reactions (1) and (3) yielded reversible electron transfers while the wave for Reaction (2) appeared to be irreversible, with a large separation between the anodic and cathodic peak potentials. Fig. 1 shows the voltammograms for $\mathrm{Co}^{\mathrm{II}}(\mathrm{OEP}$ one); similar voltammograms were obtained for $\mathrm{Co}^{\mathrm{II}}$ (OEPdione). This behavior has been seen for other $\mathrm{Co}$ (II) porphyrins [2] and [4], and is attributed to ligand exchange in Reaction (2). 
NOT THE PUBLISHED VERSION; this is the author's final, peer-reviewed manuscript. The published version may be accessed by following the link in the citation at the bottom of the page.



Fig. 1. Cyclic voltammogram for $0.80 \mathrm{mMCoII}($ OEPone) in THF/0.10 M TBAP. Gold working electrode; $\mathrm{Ag} / \mathrm{AgCl}$ reference electrode, potentials corrected to SCE. Scan rate: $100 \mathrm{mV} / \mathrm{s}$.

\subsection{Spectroelectrochemical reduction of cobalt(II)}

In order to characterize the products of the electrochemical reactions, visible and infrared spectroelectrochemistry was carried out, and, for visible spectroelectrochemistry, compared to $\mathrm{Co}^{\mathrm{II}}(\mathrm{OEP})$. The visible spectroelectrochemistry for the reduction of $\mathrm{CO}^{\mathrm{II}}(\mathrm{OEP})$ is shown in Fig 2. Isobestic points were observed in the reduction, and $\mathrm{CO}^{\mathrm{II}}(\mathrm{OEP})$ was completely regenerated upon re-oxidation. Complete reduction of $\mathrm{CO}^{\mathrm{II}}(\mathrm{OEP})$ to $\mathrm{Co}(\mathrm{OEP})^{-}$occurred at the end of the forward scan, and the spectral parameters for Co(OEP)- ${ }^{-}$were calculated (Table 1). Very little change was observed in the Q-band at $548 \mathrm{~nm}$, but the Soret band split upon reduction with $\lambda_{\max }$ values at 350 and $394 \mathrm{~nm}$. The $E_{1 / 2}$ value was calculated directly from the spectroelectrochemical data using the calculated concentrations of $\mathrm{Co}^{\mathrm{II}}(\mathrm{OEP})$ and $\mathrm{Co}^{\mathrm{I}}(\mathrm{OEP})^{-}$. This is equivalent to DCVA (derivative cyclic voltabsorptometry) [24]. This allows us to correct for the hysteresis that occurs due to the large uncompensated resistance in the thin-layer cell. The $E_{1 / 2}$ value is given in Table 2. 
NOT THE PUBLISHED VERSION; this is the author's final, peer-reviewed manuscript. The published version may be accessed by following the link in the citation at the bottom of the page.

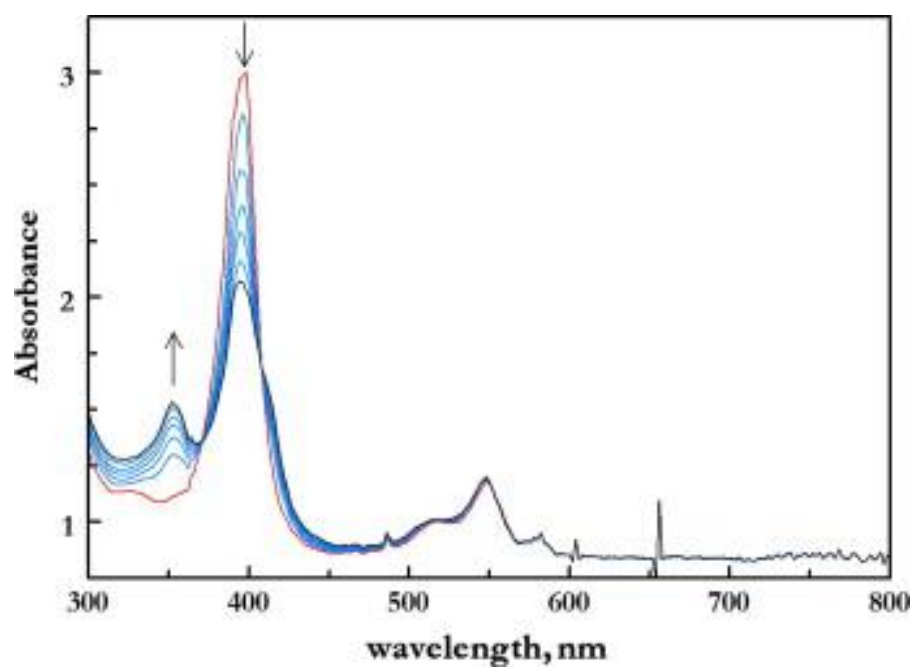

Fig. 2. Visible spectroelectrochemistry for the reduction of $0.80 \mathrm{mMCo}(\mathrm{OEP})$ in THF with $0.10 \mathrm{M}$ TBAP. Solid red line is the initial scan; solid black line is the final scan; solid blue lines are the intermediate spectra. Scan rate $=8.3 \mathrm{mV} / \mathrm{s} ; E_{\mathrm{i}}=-0.830 \mathrm{~V}$; $E_{\mathrm{f}}=-1.800 \mathrm{~V}$ vs. Ag wire. (For interpretation of the references to color in this figure legend, the reader is referred to the web version of this article.)

Table 1. Visible spectra of cobalt porphinones in THF. Compounds Soret bands $(\mathbf{n m})$ Other bands $(\mathrm{nm})$

\begin{tabular}{|c|c|c|}
\hline $\mathrm{Co}^{\mathrm{II}}(\mathrm{OEP})$ & 396 & 548 \\
\hline $\mathrm{Co}^{\mathrm{I}}(\mathrm{OEP})^{-}$ & $350,412 s, 394$ & 548 \\
\hline $\mathrm{Co}^{\mathrm{II}}$ (OEPone) & 374,412 & 606 \\
\hline $\mathrm{Co}^{\mathrm{I}}(\mathrm{OEP} \text { one })^{-}$ & 354,412 & 510,606 \\
\hline CoIII(OEPone)Cl & 416 & 610 \\
\hline $\mathrm{Co}^{\mathrm{III}}$ (OEPone) $\mathrm{Cl}^{+}$ & 406 & 690 broad \\
\hline $\mathrm{Co}^{\mathrm{II}}$ (OEPdione) & 384,432 & 620 \\
\hline $\mathrm{Co}^{\mathrm{I}}$ (OEPdione)- & 382 & 544,620 \\
\hline $\mathrm{Co}^{\mathrm{III}}$ (OEPdione)Cl & 468 & 624 \\
\hline $\mathrm{Co}^{\mathrm{III}}$ (OEPdione) $\mathrm{Cl}^{+}$ & 364,436 & 700 broad \\
\hline
\end{tabular}


Table 2. Cyclic voltammetry of cobalt porphyrins and porphinones in THF/0.10 M TBAP.

Compounds Reduction $E_{1 / 2^{\mathrm{a}}}$ (V) Oxidation $E_{1 / 2,1}(V) E_{1 / 2,2^{\mathrm{a}}}$ (V) Ref.

\begin{tabular}{|c|c|c|c|c|}
\hline $\mathrm{CO}^{\mathrm{II}}(\mathrm{OEP})$ & -1.05 & - & - & This work \\
\hline $\mathrm{Co}^{\mathrm{II}}$ (OEPone) & -1.03 & $+0.90^{\underline{b}}$ & +1.16 & This work \\
\hline CoII(OEPdione) & -1.02 & $+0.97 \underline{b}$ & +1.10 & This work \\
\hline $\mathrm{Fe}^{\mathrm{II}}(\mathrm{OEP})$ & -1.26 & -0.45 & 1.19 & [11] \\
\hline $\mathrm{Fe}^{\mathrm{II}}$ (OEPone) & -1.23 & -0.35 & 1.02 & [11] \\
\hline $\mathrm{Fe}^{\mathrm{II}}$ (OEPdione) & -1.15 & -0.16 & 0.96 & [11] \\
\hline
\end{tabular}

a $V$ vs. $\mathrm{SCE}$, measured $V$ vs. $\mathrm{Ag} / \mathrm{AgClO}_{4}\left(V\right.$ vs. $\mathrm{SCE}=V$ vs. $\left.\mathrm{Ag} / \mathrm{AgClO}_{4}+0.17 \mathrm{~V}\right)$.

${ }^{\mathrm{b}} E_{\mathrm{p}}, V$ vs. SCE.

The reductions of $\mathrm{Co}^{\mathrm{II}}$ (OEPone) and $\mathrm{Co}^{\mathrm{II}}$ (OEPdione) are shown in Fig. 3a and Fig. 3b, and the spectra are summarized in Table 1. As was seen for $\mathrm{CO}^{\mathrm{I}}(\mathrm{TPP})^{-}$and $\mathrm{CO}^{\mathrm{I}}(\mathrm{OEP})^{-}$, a split Soret band was observed for $\mathrm{Co}^{\mathrm{I}}(\mathrm{OEP} \text { one })^{-}$but a single Soret band was observed for $\mathrm{Co}^{\mathrm{I}}(\mathrm{OEP} d i o n e)^{-}$. For both $\mathrm{Co}^{\mathrm{I}}(\mathrm{OEP} \text {. Fe })^{-}$and $\mathrm{Co}^{\mathrm{I}}(\mathrm{OEPdione})^{-}$, a new band appeared in the $\mathrm{Q}$ band region (510 and $544 \mathrm{~nm}$, respectively), but the original $\mathrm{Q}$ band remained with small changes in absorbance. Using the same procedure as was used for $\mathrm{Co}^{\mathrm{II}}(\mathrm{OEP})$, the $E_{1 / 2}$ values for $\mathrm{Co}^{\mathrm{II}}\left(\mathrm{OEP}\right.$ ne) and $\mathrm{Co}^{\mathrm{II}}$ (OEPdione) were calculated (Table 2). The macrocycle had a smaller effect on the cobalt(II) complexes (30 mV decrease from OEP to OEPdione) than for the iron(II) complexes (110 mV) (Table 2).

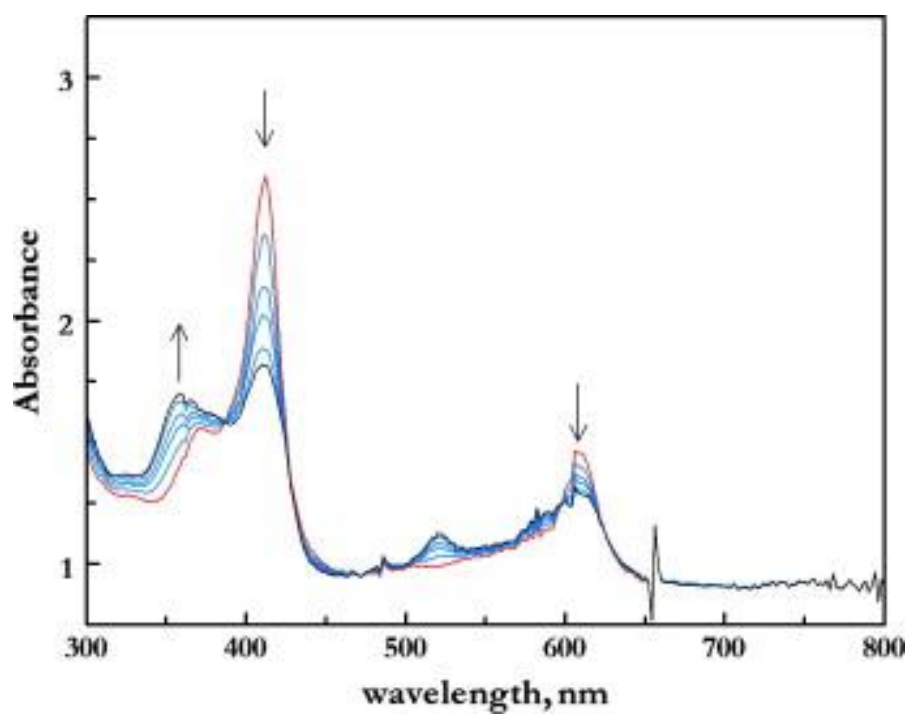

Fig. 3a. Visible spectroelectrochemistry for the reduction of $0.80 \mathrm{mMCo}$ (OEPone) in THF with 0.10 M TBAP. Solid red line is the initial scan; solid black line is the final scan; solid blue lines are the intermediate spectra. Scan rate $=8.3 \mathrm{mV} / \mathrm{s} ; E_{\mathrm{i}}=0.00 \mathrm{~V}$; 
$E_{f}=-1.90 \mathrm{~V}$ vs. Ag wire. (For interpretation of the references to color in this figure legend, the reader is referred to the web version of this article.)

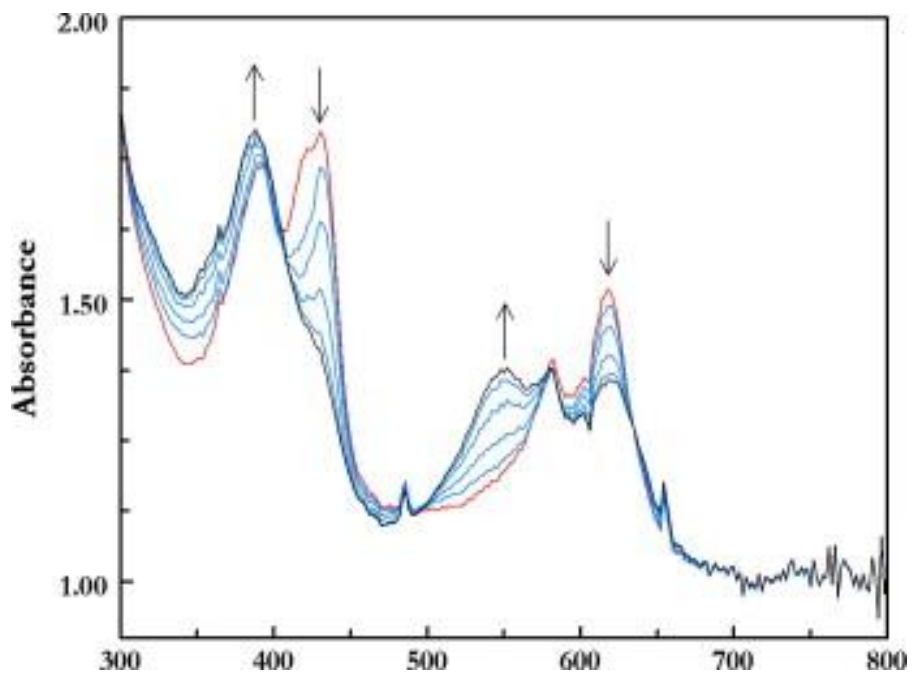

Fig. 3b. Visible spectroelectrochemistry for the reduction of $0.80 \mathrm{mMCo}$ (OEPdione) in THF with $0.10 \mathrm{M}$ TBAP. Solid red line is the initial scan; solid black line is the final scan; solid blue lines are the intermediate spectra. Scan rate $=8.0 \mathrm{mV} / \mathrm{s}$; $E_{\mathrm{i}}=-0.500 \mathrm{~V} ; E_{\mathrm{f}}=-1.500 \mathrm{~V}$ vs. Ag wire. (For interpretation of the references to color in this figure legend, the reader is referred to the web version of this article.)

In order to probe the structure of the cobalt(I) complexes, infrared spectroelectrochemistry was carried out. The carbonyl bands for these macrocycles are quite strong and can be readily observed in 2-3 mM solutions. The infrared spectroelectrochemical reduction of $\mathrm{Co}^{\mathrm{II}}$ (OEPone) is shown in Fig 4. The cobalt(II) complex had bands at $1709\left(v_{\mathrm{co}}\right), 1589$ and $1562 \mathrm{~cm}^{-1}$. The solvent cutoff at $1500 \mathrm{~cm}^{-1}$ makes it difficult to observe bands that are of lower energies. Upon reduction, the $v_{\mathrm{co}}$ band decreased to $1674 \mathrm{~cm}^{-1}$, with new bands at $1616,1593,1578$ and $1551 \mathrm{~cm}^{-1}$. The decrease in the carbonyl band was quite similar to that observed for $\mathrm{Fe}^{\mathrm{II}}$ (OEPone) reduction (Table $\underline{3})$. In order to better characterize the energy shifts, ${ }^{18} \mathrm{O}$ substituted $\mathrm{H}_{2}$ OEPone was synthesized. The vibrational bands for $\mathrm{Co}^{\mathrm{II}}\left({ }^{16 / 18} \mathrm{O}-\right.$ OEPone) and $\mathrm{Co}^{\mathrm{I}}\left({ }^{16 / 18} \mathrm{O}-\mathrm{OEP}\right.$ one $)$ are summarized in Table 3 . In this table, the $v_{\text {co }}$ bands predicted by the DFT calculations are given in parentheses. For the $\mathrm{Co}^{\mathrm{II}}$ (OEPone) spectrum, the $v_{\mathrm{co}}$ band decreased from 1709 to $1680 \mathrm{~cm}^{-1}$ upon ${ }^{18} \mathrm{O}$ substitution, a shift of $29 \mathrm{~cm}^{-1}$. This compares with a $26 \mathrm{~cm}^{-1}$ shift predicted by DFT calculations. No measurable shifts were observed for the 1592 and $1562 \mathrm{~cm}^{-1}$ bands. For the CoI complex, a shift of $20 \mathrm{~cm}^{-1}\left(13 \mathrm{~cm}^{-1}\right.$ by DFT) was observed for the carbonyl band. The 1616 and $1551 \mathrm{~cm}^{-1}$ bands were 
unchanged, but a $2 \mathrm{~cm}^{-1}$ shift was observed for the $1593 \mathrm{~cm}^{-1}$ band, and a $1 \mathrm{~cm}^{-1}$ shift for the $1578 \mathrm{~cm}^{-1}$.

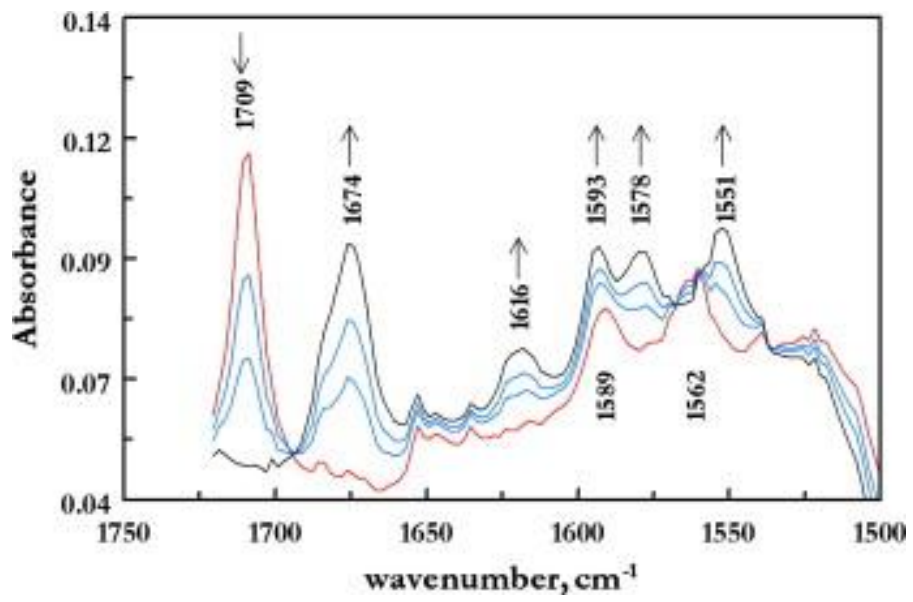

Fig. 4. Infrared spectroelectrochemistry for the reduction of $3.0 \mathrm{mMCo}(\mathrm{OEP}$ THF with $0.10 \mathrm{M}$ TBAP. Solid red line is the initial scan; solid black line is the final scan; solid blue lines are the intermediate spectra. $E=-1.50 \mathrm{~V}$ vs. Ag wire; 32 scans; $2 \mathrm{~cm}^{-1}$ resolution. (For interpretation of the references to color in this figure legend, the reader is referred to the web version of this article.)

Table 3. Infrared spectra of cobalt and iron porphinones. $\underline{a}$

\begin{tabular}{|c|c|c|c|}
\hline & $v_{\text {co }}\left(\mathrm{cm}^{-1}\right)$ & Other bands $\left(\mathrm{cm}^{-1}\right)$ & Refs \\
\hline \multirow{3}{*}{ CoII(OEPone) } & $1709(1700)$ & 1589,1562 & tw \\
\hline & $1709 \underline{b}$ & $\begin{array}{l}\text { 1592, 1562, 1455, 1395, 1377, } \\
1311,1268,1222\end{array}$ & tw \\
\hline & $1680(1674)$ & 1591,1562 & tw \\
\hline $\mathrm{Co}^{\mathrm{II}}\left({ }^{18} \mathrm{O}-\mathrm{OEP}\right.$ ene $)$ & $1679 \underline{b}$ & $\begin{array}{l}1492,1564,1455,1396,1376 \\
1309,1270,1234,1222\end{array}$ & tw \\
\hline $\mathrm{Co}^{\mathrm{I}}(\mathrm{OEP} \text {-ne })^{-}$ & $1674(1661)$ & $1616,1593,1578,1551$ & tw \\
\hline $\mathrm{Co}^{\mathrm{I}}\left({ }^{18} \mathrm{OEP} \text { (nne) }\right)^{-}$ & $1654(1652)$ & $1616,1591,1578,1551$ & tw \\
\hline CoIII(OEPone)Cl & $1715(1704)$ & 1591,1566 & tw \\
\hline $\mathrm{CO}^{\mathrm{III}}\left({ }^{18} \mathrm{O}-\mathrm{OEP}\right.$ one $) \mathrm{Cl}$ & $1684(1674)$ & 1590,1563 & tw \\
\hline $\mathrm{Co}^{\mathrm{III}}$ (OEPone) $\mathrm{Cl}^{+}$ & 1736 & 1569 & tw \\
\hline $\mathrm{Co}^{\mathrm{II}}$ (OEPdione) & 1709 & $1605,1581,1559$ & tw \\
\hline $\mathrm{CO}^{\mathrm{I}}$ (OEPdione)- & 1683,1668 & 1605,1576 & tw \\
\hline $\mathrm{Co}^{\mathrm{III}}$ (OEPdione)Cl & $1721(1705)$ & 1610,1584 & tw \\
\hline $\mathrm{Co}^{\mathrm{III}}$ (OEPdione) $\mathrm{Cl}^{+}$ & 1734 & 1580 & tw \\
\hline $\mathrm{Fe}^{\mathrm{III}}($ OEPone)Cl & $1719(1706)^{\complement}$ & 1563,1536 & [11] \\
\hline $\mathrm{Fe}^{\mathrm{II}}$ (OEPone) & $1703(1697)^{\complement}$ & 1550,1536 & [11] \\
\hline $\mathrm{Fe}^{\mathrm{I}}(\mathrm{OEP} o n e)^{-}$ & $1671(1655)$ & $1609,1578,1548,1526$ & {$[11]$} \\
\hline $\mathrm{Fe}^{\mathrm{III}}$ (OEPdione)Cl & $1717(1706)$ & $1580,1560,1543,1526$ & [11] \\
\hline
\end{tabular}

Journal of Electroanalytical Chemistry, Vol. 670 (April 1, 2012): pg. 16-22. DOI. This article is (C Elsevier and permission has been granted for this version to appear in e-Publications@Marquette. Elsevier does not grant permission for this article to be further copied/distributed or hosted elsewhere without the express permission from Elsevier. 
NOT THE PUBLISHED VERSION; this is the author's final, peer-reviewed manuscript. The published version may be accessed by following the link in the citation at the bottom of the page.

\begin{tabular}{|c|c|c|c|}
\hline & $V_{c o}\left(\mathrm{~cm}^{-1}\right)$ & Other bands $\left(\mathrm{cm}^{-1}\right)$ & Refs. \\
\hline $\mathrm{Fe}^{\mathrm{II}}$ (OEPdione) & 1703 & 1547,1524 & [11] \\
\hline $\mathrm{Fe}^{\mathrm{I}}$ (OEPdione)- & $\begin{array}{l}1670(1660), \\
1655(1649)\end{array}$ & 1638,1578 & [11] \\
\hline
\end{tabular}

Numbers in parentheses are the values predicted by DFT calculations for the octamethyl complexes.

$\mathrm{tw}=$ This work.

a In THF and 0.10 M TBAP unless noted.

b In $\mathrm{KBr}$ pellet.

c Calculation from this work.

The infrared spectroelectrochemistry and the DFT calculations are consistent with primarily metal(I) complexes for $\mathrm{Fe}^{\mathrm{I}}(\mathrm{OEPone})^{-}$and $\mathrm{Co}^{\mathrm{I}}$ (OEPone $)^{-}$. The electronic structure of the metals, using NBO (natural bond orbital analysis), is confirmed by the DFT calculations. Previous experimental work has indicated that $\mathrm{Co}(\mathrm{P})^{-}$contains a cobalt(I) species, as discussed in Section $\underline{1}$. The NBO analysis for $\mathrm{Co}^{\mathrm{I}}$ (OEPone $)^{-}$led to a similar conclusion $\left(3 \mathrm{~d}^{8}\right.$, NBO value by DFT was 7.65). The structure for $\mathrm{Fe}^{\mathrm{I}}\left(\mathrm{OEP}\right.$ (One) ${ }^{-}$has been more controversial. The NBO analysis by DFT indicated a $3 d^{7}$ configuration (6.85), consistent with an iron(I) complex. The consistency between the experimental shifts in the infrared spectra and those calculated by DFT lends credence to the calculated electronic structures.

While both structures are consistent with metal(I) complexes, the shifts in the $v_{\text {co }}$ band that were observed for the reduction of the metal(II) to metal(I) complex were about $7 \mathrm{~cm}^{-1}$ smaller for the cobalt complexes, as compared to the iron complexes. DFT calculations indicate that the electron density in the HOMO orbital of $\mathrm{Co}(\mathrm{I})$ (OMPone)- (OMPone $=$ octamethylporphinone) was almost exclusively centered on the $d_{z 2}$ orbital of cobalt, with much less localization than was observed for iron. This is consistent with our supposition that increased delocalization of the electron from the metal to the ligand would lead to greater weakening of the carbonyl bond, and lower energy for the $v_{\mathrm{co}}$ band.

The infrared spectroelectrochemistry of $\mathrm{Co}^{\mathrm{II}}$ (OEPdione) reduction is shown in Fig 5 . A single carbonyl band was observed for the cobalt(II) complex $\left(1709 \mathrm{~cm}^{-1}\right)$, essentially the same as was observed for the $\mathrm{Co}^{\mathrm{II}}$ (OEPone) complex. Upon reduction, the carbonyl band was split into two bands at 1683 and $1668 \mathrm{~cm}^{-1}$. The $1605 \mathrm{~cm}^{-1}$

Journal of Electroanalytical Chemistry, Vol. 670 (April 1, 2012): pg. 16-22. DOI. This article is (C) Elsevier and permission has been granted for this version to appear in e-Publications@Marquette. Elsevier does not grant permission for this article to be further copied/distributed or hosted elsewhere without the express permission from Elsevier. 
band was essentially unchanged upon reduction, but the 1581 and $1559 \mathrm{~cm}^{-1}$ bands disappeared and a new band at $1576 \mathrm{~cm}^{-1}$ appeared, whose broadness indicates that there may be two or more bands present. There are similarities and differences between the cobalt(I) and iron(I) OEPdione complexes. The higher energy $v_{\text {co }}$ band for the iron(I) complex shifts to a lower energy $\left(1670 \mathrm{~cm}^{-1}\right)$ than the cobalt(I) complex. In addition, a strong band was observed at $1605 \mathrm{~cm}^{-1}$ for cobalt(I), while no band of similar absorbance was observed for iron(I). Both cobalt(I) and iron(I) had strong bands at about $1577 \mathrm{~cm}^{-1}$, with shoulders at lower energy.

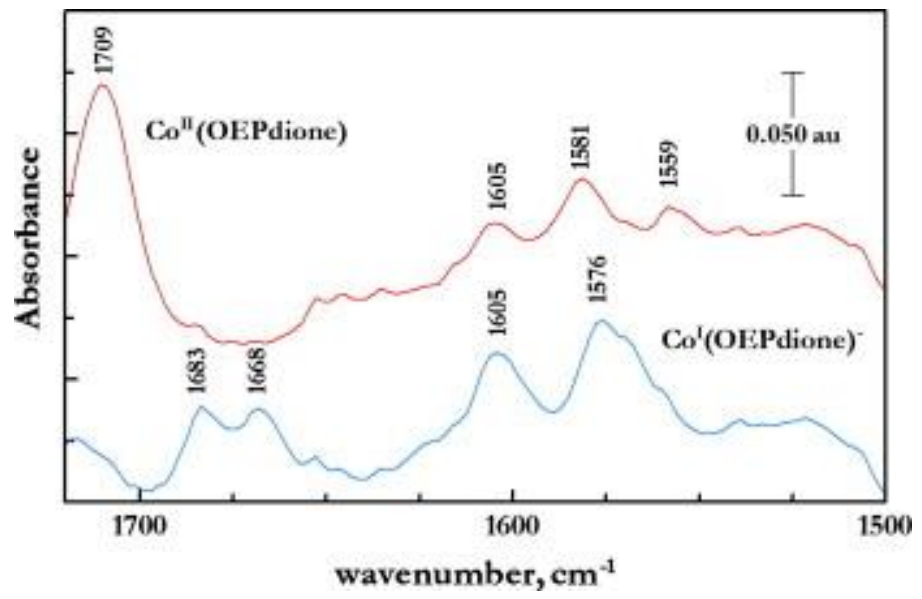

Fig. 5. Infrared spectroelectrochemistry for the reduction of $3.0 \mathrm{mMCo}$ (OEPdione) in THF with $0.10 \mathrm{M}$ TBAP. Solid red line is the initial scan; solid blue line is the final scan. $E=-1.5 \mathrm{~V}$ vs. Ag wire, 32 scans, $2 \mathrm{~cm}^{-1}$ resolution. (For interpretation of the references to color in this figure legend, the reader is referred to the web version of this article.)

\subsection{Spectroelectrochemical oxidation of cobalt(II)}

The oxidation of $\mathrm{Co}^{\mathrm{II}}$ (OEPone) and $\mathrm{Co}^{\mathrm{II}}$ (OEPdione) was carried out using visible and infrared spectroscopy. The oxidation of the cobalt(II) complexes were performed in the presence of chloride (as tetraphenylphosphonium chloride) in order to ensure the identity of the axial ligand for the oxidation products. The oxidation of $\mathrm{Co}^{\mathrm{II}}$ (OEPone) to $\mathrm{Co}^{\mathrm{III}}$ (OEPone) $\mathrm{Cl}$ showed relatively few changes in the visible spectra as is typical for metal-based electron transfers (Fig 6). The Soret band was shifted from 412 to $416 \mathrm{~nm}$ with a shoulder at $430 \mathrm{~nm}$. The small band at $370 \mathrm{~nm}$ was attenuated, and the 610 band shifted to $612 \mathrm{~nm}$. For the oxidation of $\mathrm{Co}^{\mathrm{III}}$ (OEPone) $\mathrm{Cl}$, the features of the $n$-radical cation can be seen in the visible spectrum. The Soret 
band shifted from 416 to $406 \mathrm{~nm}$, while the $616 \mathrm{~nm}$ band was bleached. A weak broad band was observed at $690 \mathrm{~nm}$. In a procedure similar to calculating the $E_{1 / 2}$ for the reduction of the cobalt(II) complexes, the $E_{1 / 2}$ for the second oxidation was calculated. The results are summarized in Table 2 . Only the $E_{\mathrm{p}}$ values for the first oxidation could be found as the wave was irreversible.

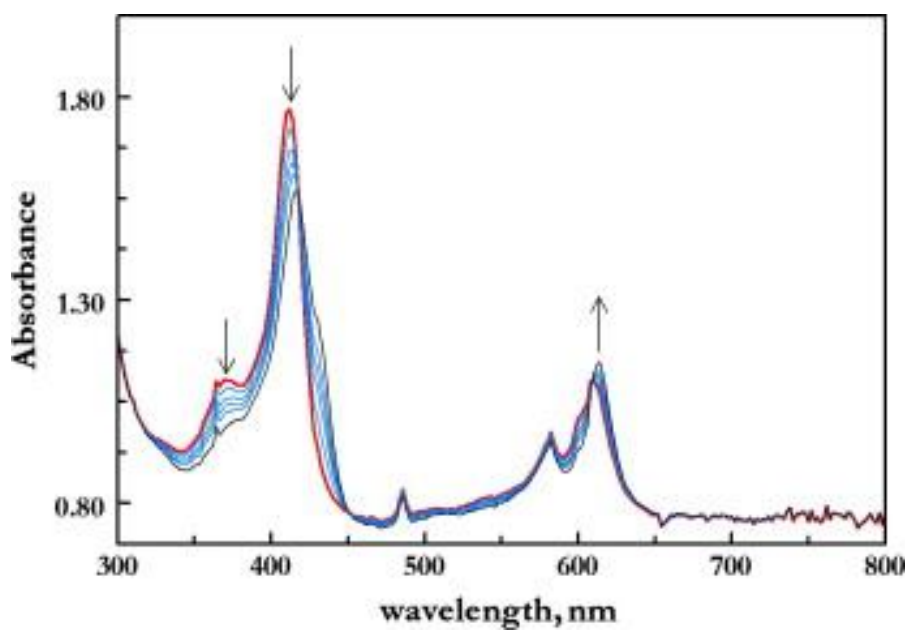

Fig. 6. Visible spectroelectrochemistry for the first oxidation of $0.80 \mathrm{mMCo}$ (OEPone) in THF with $0.10 \mathrm{M} \mathrm{TBAP} / \mathrm{Cl}^{-}$. Solid red line is the initial scan; solid black line is the final scan; solid blue lines are the intermediate spectra. Scan rate $=3.1 \mathrm{mV} / \mathrm{s}$;

$E_{\mathrm{i}}=0.000 \mathrm{~V} ; E_{\mathrm{f}}=+0.920 \mathrm{~V} \mathrm{vs}$. Ag wire. (For interpretation of the references to color in this figure legend, the reader is referred to the web version of this article.)

More significant changes were observed in the oxidation of $\mathrm{Co}^{\mathrm{II}}$ (OEPdione). The split Soret bands at 394 and $430 \mathrm{~nm}$ disappeared and a new Soret band was observed at $468 \mathrm{~nm}$ (with shoulders at 438 and $410 \mathrm{~nm}$ ). As with $\mathrm{Co}^{\mathrm{II}}$ (OEPone), there was only a small shift in the Q-band from 620 to $624 \mathrm{~nm}$. Further oxidation to $\mathrm{Co}^{\mathrm{III}}$ (OEPdione) $\mathrm{Cl}^{+}$ shifted the Soret band from 468 to $436 \mathrm{~nm}$, with a shoulder at $364 \mathrm{~nm}$ (Fig 7). The $624 \mathrm{~nm}$ band almost completely disappeared, and a new broad band at $700 \mathrm{~nm}$ appeared. The bleaching of the Q-band and a broad band around $700 \mathrm{~nm}$ are indicative of a $n$-cation radical species. 
NOT THE PUBLISHED VERSION; this is the author's final, peer-reviewed manuscript. The published version may be accessed by following the link in the citation at the bottom of the page.

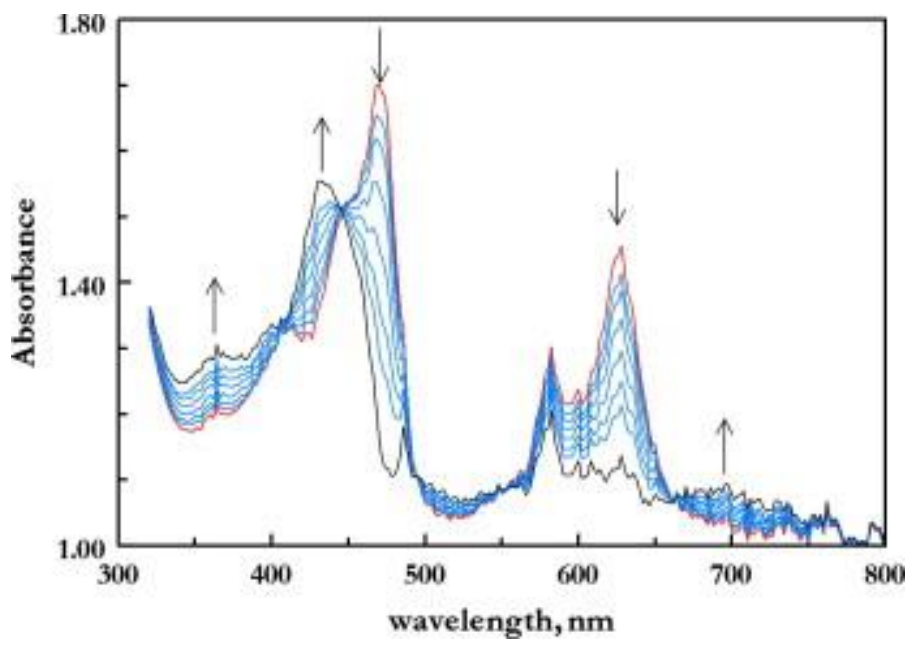

Fig. 7. Visible spectroelectrochemistry for the second oxidation of

$0.80 \mathrm{mMCo}$ (OEPdione) in THF with $0.10 \mathrm{M} \mathrm{TBAP} / \mathrm{Cl}^{-}$. Solid red line is the initial scan; solid black line is the final scan; solid blue lines are the intermediate spectra. Scan rate $=8.5 \mathrm{mV} / \mathrm{s} ; E_{\mathrm{i}}=+0.830 \mathrm{~V} ; E_{\mathrm{f}}=+1.200 \mathrm{~V}$ vs. Ag wire. (For interpretation of the references to color in this figure legend, the reader is referred to the web version of this article.)

The infrared spectroelectrochemistry of $\mathrm{CO}^{\mathrm{II}}$ (OEPone) in THF and the presence of chloride is shown in Fig 8 . There was a small upshift in the $v_{\mathrm{co}}$ band $\left(1709-1715 \mathrm{~cm}^{-1}, 6 \mathrm{~cm}^{-1}\right.$ upshift). This compares with an upshift of $4 \mathrm{~cm}^{-1}$ predicted by DFT calculations. The bands at 1589 and $1562 \mathrm{~cm}^{-1}$ diminished in absorbance but did not shift significantly. Further oxidation to the radical cation shifted the $v_{\mathrm{co}}$ band to $1736 \mathrm{~cm}^{-1}$, the 1589 and $1562 \mathrm{~cm}^{-1}$ bands disappeared, and a new band was observed at $1569 \mathrm{~cm}^{-1}$. The NBO analysis (7.38) of $\mathrm{Co}^{\mathrm{III}}$ (OEPone)Cl was consistent with a $3 \mathrm{~d}^{7}$ structure for cobalt. 
NOT THE PUBLISHED VERSION; this is the author's final, peer-reviewed manuscript. The published version may be accessed by following the link in the citation at the bottom of the page.

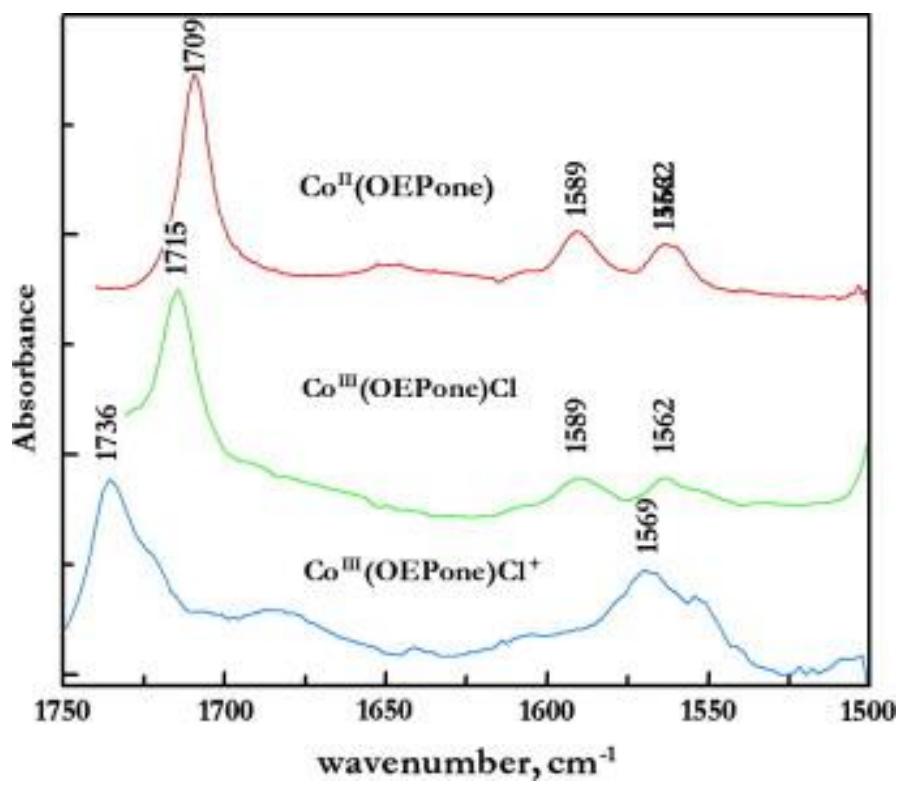

Fig. 8. Infrared spectroelectrochemistry for the oxidation of $3.0 \mathrm{mMCo}(O E P o n e)$ in THF with $0.10 \mathrm{M}$ TBAP. Solid red line is the initial scan; solid green line is the first oxidation product $(\mathrm{Co}(\mathrm{OEP}$ ne $) \mathrm{Cl}, E=+1.0 \mathrm{~V})$; solid blue line is the second oxidation product ( $\mathrm{Co}(\mathrm{OEPone}) \mathrm{Cl}^{+}, E=+1.5 \mathrm{~V}$ ). 32 scans, $2 \mathrm{~cm}^{-1}$ resolution. (For interpretation of the references to color in this figure legend, the reader is referred to the web version of this article.)

The oxidation of $\mathrm{Co}^{\mathrm{II}}$ (OEPdione) showed a much greater sensitivity of the $v_{\mathrm{CO}}$ band to the metal oxidation state, with a shift from $1709 \mathrm{~cm}^{-1}$ to $1721 \mathrm{~cm}^{-1}$ (Fig 9). This shift is similar to that observed for the $\mathrm{Fe}^{\mathrm{III}} / \mathrm{Fe}^{\mathrm{II}}$ complexes of the same macrocycle $\left(14 \mathrm{~cm}^{-1}\right)$. Further oxidation to the radical cation up shifted the $v_{\mathrm{CO}}$ band to $1734 \mathrm{~cm}^{-1}$. The 1589 and $1605 \mathrm{~cm}^{-1}$ bands of the cobalt(II) complex shifted about 3-5 $\mathrm{cm}^{-1}$ higher in energy. Further oxidation led to a decrease in the bands as was observed for the cobalt-OEPone complex, with the new broad band at about $1580 \mathrm{~cm}^{-1}$. 
NOT THE PUBLISHED VERSION; this is the author's final, peer-reviewed manuscript. The published version may be accessed by following the link in the citation at the bottom of the page.



Fig. 9. Infrared spectroelectrochemistry for the oxidation of $3.0 \mathrm{mMCo}$ (OEPdione) in THF with $0.10 \mathrm{M}$ TBAP. Solid red line is the initial scan; solid green line is the first oxidation product $(\mathrm{Co}(\mathrm{OEPdione}) \mathrm{Cl}, E=+1.0 \mathrm{~V})$; solid blue line is the second oxidation product (Co(OEPdione)Cl $\left.{ }^{+}, E=+1.5 \mathrm{~V}\right) .32$ scans; $2 \mathrm{~cm}^{-1}$ resolution. (For interpretation of the references to color in this figure legend, the reader is referred to the web version of this article.)

The oxidation of cobalt(II) complexes can be compared to the reduction of iron(III) complexes, as the same redox states (III/II) are involved. The carbonyl band was relatively insensitive to the oxidation state of the cobalt whrn the complex was oxidized to the cobalt(III) state. The oxidation led to an upshift of $6 \mathrm{~cm}^{-1}\left(4 \mathrm{~cm}^{-1}\right.$ by DFT) for the porphinone complex and an increase of $12 \mathrm{~cm}^{-1}$ for the porphinedione complex. This compares with observed shifts of 16 and $14 \mathrm{~cm}^{-1}$ respectively for the porphinone and porphinedione complexes of iron. The smaller shift may be due to the fact that the cobalt(III) complex is a $\mathrm{d}^{6}$ complex and is better able to back bond through the $d_{n}$ orbitals than iron(III), a $d^{5}$ complex. Further increases in the $v_{\text {Co }}$ band were observed in the formation of the radical cation, but the observed shifts (21 and $13 \mathrm{~cm}^{-1}$ ) are smaller than those observed for the reduction of cobalt(II) ( 25 and $21 \mathrm{~cm}^{-1}$ ). The carbonyl frequency appears to be less sensitive to oxidation then towards reduction, which may be due to the electron withdrawing nature of the functional group.

\section{Conclusions}

The spectroelectrochemical results for the reduction of cobalt(II) porphinone and porphinedione are in agreement with this empirical rules for metal centered process. A small decrease and shift in the 
Soret band, coupled with the absence of band broadening in the UV and visible region, are consistent with the metal centered process. The IR spectroelectrochemistry of CoIIOEPone showed a downshift in the carbonyl band of $33 \mathrm{~cm}^{-1}$ which was similar to that carbonyl shift observed for $\mathrm{Fe}^{\mathrm{II}}$ (OEPone) $\left(32 \mathrm{~cm}^{-1}\right)$. The carbonyl vibration was weakened due to the increase electron density on the porphyrins ring caused by back bonding from the metal to the porphyrins.

The cobalt complexes displayed two one-electron oxidations, the first was considered to be metal centered while the second led to the formation of a $n$-radical cation. The spectral changes for the first oxidation of cobalt porphinone and porphinedione are consistent with a metal centered. The Soret band shifted but the molar absorptivity was preserved. No band broadening was observed in UV and visible region. The second oxidation process showed a shift in the Soret band while the Q-band became featureless with the appearance of a broadband in the visible region. All of these changes indicated a porphyrin centered process according to previous literature.

This work shows the advantage of combining several spectroscopic techniques with electrochemistry in order to generate and characterize redox processes. The results are consistent with a primarily metal-based reduction of cobalt(II) and iron(II) complexes to give their respective metal(I) complexes. Further work in our laboratory on zinc(II) and manganese(II) complexes are being carried out provide additional evidence for these observations.

\section{References}

[1] Z. Wei, M.D. Ryan. Inorg. Chem., 49 (2010), p. 6948

[2] K.M. Kadish, X.Q. Lin, B.C. Han. Inorg. Chem., 26 (1987), p. 4161

[3] X.H. Mu, X.Q. Lin, K.M. Kadish. Electroanalysis, 1 (1989), p. 113

[4] F. D'Souza, A. Villard, E. Van Caemelbecke, M. Franzen, T. Boschi, P. Tagliatesta, K.M. Kadish. Inorg. Chem., 32 (1993), p. 4042

[5] F.A. Walker, D. Beroiz, K.M. Kadish. J. Am. Chem. Soc., 98 (1976), p. 3484

[6] H. Kobayashi, T. Hara, Y. Kaizu. Bull. Chem. Soc. Jpn., 45 (1972), p. 2148

[7] P. Doppelt, J. Fischer, R. Weiss. Inorg. Chem., 23 (1984), p. 2958

[8] A.S. Hinman, T. Olorunyolemi. Can. J. Chem., 71 (1993), p. 1975

[9] D.H. Jones, A.S. Hinman. J. Chem. Soc. Dalton Trans. (1992), p. 1503

Journal of Electroanalytical Chemistry, Vol. 670 (April 1, 2012): pg. 16-22. DOI. This article is @ Elsevier and permission has been granted for this version to appear in e-Publications@Marquette. Elsevier does not grant permission for this article to be further copied/distributed or hosted elsewhere without the express permission from Elsevier. 
[10] A.S. Hinman, B.J. Pavelich, K. McGarty. Can. J. Chem., 66 (1988), p. 1589

[11] Y. Liu, M.D. Ryan. Inorg. Chim. Acta, 225 (1994), p. 57

[12] Y.M. Liu, C. DeSilva, M.D. Ryan. Inorg. Chim. Acta, 258 (1997), p. 247

[13] J.H. Fuhrhop, K.M. Kadish, D.G. Davis. J. Am. Chem. Soc., 95 (1973), p. 5140

[14] A. Salehi, W.A. Oertling, G.T. Babcock, C.K. Chang. J. Am. Chem. Soc., 108 (1986), p. 5630

[15] W.A. Oertling, A. Salehi, Y.C. Chung, G.E. Leroi, C.K. Chang, G.T. Babcock. J. Phys. Chem., 91 (1987), p. 5887

[16]W.A. Oertling, A. Salehi, C.K. Chang, G.T. Babcock. J. Phys. Chem., 93 (1989), p. 1311

[17]Z. Gasyna, M.J. Stillman. Inorg. Chem., 29 (1990), p. 5101

[18]C.K. Chang, C. Sotiriou. J. Org. Chem., 50 (1985), p. 4989

[19]C.K. Chang, C. Sotiriou, W. Wu. J. Chem. Soc. Chem. Commun. (1986), p. 1213

[20] W. Wu, C.K. Chang. J. Am. Chem. Soc., 109 (1987), p. 3149

[21] X.Q. Lin, K.M. Kadish. Anal. Chem., 57 (1985), p. 1498

[22]M.J. Frisch, G.W. Trucks, H.B. Schlegel, G.E. Scuseria, M.A. Robb, J.R. Cheeseman, G. Scalmani, B. Barone, B. Mennucci, G.A. Petersson, H. Natatsuji, M. Caricota, X. Li, H.P. Hratchian, A.F. Izmaylov, J. Bloino, G. Zheng, J.L. Sonnenberg, M. Hada, K. Toyota, R. Fukuda, J. Hasegawa, M. Ishida, T. Nakajima, Y. Honda, O. Kitao, H. Nakai, T. Vreven, J.A. Montgomery Jr., J.E. Peralta, F. Ogliaro, M. Bearpark, J.J. Heyd, E. Brothers, K.N. Kudin, V.N. Staroverov, R. Kobayashi, J. Normand, K. Raghavachari, A. Rendell, J.C. Burant, S.S. Iyengar, J. Tomasi, M. Cossi, N. Rega, N.J. Millam, M. Klene, J.E. Knox, J.B. Cross, V. Bakken, C. Adamo, J. Jaramillo, R. Gomperts, R.E. Stratmann, O. Yazyev, A.J. Austin, R. Cammi, C. Pomelli, J.W. Ochterski, R.L. Martin, K. Morokuma, V.G. Zakrzewski, G.A. Voth, P. Salvador, J.J. Dannenberg, S. Dapprich, A.D. Daniels, Ö. Farkas, J.B. Foresman, J.V. Ortiz, J. Cioslowski, D.J. Fox. Gaussian G09, revision B.01. Gaussian, Inc., Wallingford, CT (2009)

[23] A.J.H. Wachters. J. Chem. Phys., 52 (1970), p. 1033

[24]E.E. Bancroft, J.S. Sidwell, H.N. Blount. Anal. Chem., 53 (1981), p. 1390

Corresponding author. Tel.: +1 414288 1625; fax: +1 4142887066 .

Journal of Electroanalytical Chemistry, Vol. 670 (April 1, 2012): pg. 16-22. DOI. This article is ( Elsevier and permission has been granted for this version to appear in e-Publications@Marquette. Elsevier does not grant permission for this article to be further copied/distributed or hosted elsewhere without the express permission from Elsevier. 